\title{
Dynamic Analysis on the Safety Criteria of the Conceptual Core Design in MTR-type Research Reactor
}

\author{
T. Surbakti, S. Pinem and L. Suparlina \\ Center for Nuclear Reactor Technology and Safety, National Nuclear Energy Agency, \\ Puspiptek Area, Serpong, Tangerang Selatan 15130, Indonesia
}

\section{ARTICLE INFO}

\section{Article history:}

Received 31 October 2016

Received in revised form 21 Juni 2017

Accepted 23 February 2018

\section{Keywords:}

MTR-type research reactor

Control rod velocity

High uranium density

MTR-DYN code

\begin{abstract}
A B S T R A C T
One of the high-priority research activities in BATAN is designing a new MTRtype research reactor with a new fuel. The core follows a compact core model that consists of 16 fuels and 4 control rods. The increasing heat flux at the fuel will cause the temperature of the fuel and cladding to increase so that the coolant flow rate needs to be increased. However, the coolant flow rate in the fuel element is limited by the thermal-hydraulic stability in the core. Therefore, dynamic analysis is important in evaluating the design and operation of nuclear reactor safety. The objective of this research work is to carry out a dynamic analysis for a conceptual MTR research reactor core fuelled with the low-enrichment U9Mo-Al dispersion. The calculations were performed using WIMSD-5B, Batan-2DIFF, Batan-3DIFF, POKDYN, and MTRDYN codes. Steady-state thermal-hydraulic parameters and dynamic analysis were determined using the MTRDYN code. The calculation results show that the maximum temperatures of the coolant, cladding, and fuel meat with the uranium density of $3.96 \mathrm{~g} \mathrm{~cm}^{-3}$ are $76.01{ }^{\circ} \mathrm{C}$, $192.02{ }^{\circ} \mathrm{C}$, and $196.24{ }^{\circ} \mathrm{C}$, respectively. The maximum value of fuel meat temperature for safety limit is $210^{\circ} \mathrm{C}$, which means that the maximum temperatures fulfill the design limit, and therefore the reactor operates safely at the nominal power. The dynamic analysis shows that inherent safety can protect the reactor operation when insertion of reactivity occurs in the core.
\end{abstract}

(C) 2018 Atom Indonesia. All rights reserved

\section{INTRODUCTION}

One of the high-priority research activities in the Center for Nuclear Reactor Technology and Safety-BATAN is the design of a new research reactor using uranium-molybdenum fuel (U9Mo-Al). High loading of fissile material in the U9Mo-Al fuel is expected to increase the operation cycle; hence, higher reactor availability and utilization can be achieved while the fuel cost can be reduced [1].

An early conceptual design of Material Testing Reactor (MTR) type from neutronics aspect has been derived by T. Surbakti, et al., [2] whose main core configuration characteristics are as specified as follows. The MTR research reactor has

\footnotetext{
${ }^{*}$ Corresponding author.

E-mail address: tukiran@batan.go.id

DOI: https://doi.org/10.17146/aij.2018.545
}

a nominal power of $20 \mathrm{MW}$. It uses a uraniummolybdenum alloy, U9Mo-Al, fuel with a geometry adopted from the fuel of the G.A. Siwabessy Multipurpose Reactor (RSG-GAS). The core configuration in a $5 \times 5$ lattice consists of 20 fuel elements and five irradiation positions and produces thermal neutron flux in the order of $2.87 \times 10^{14}$ neutron $\mathrm{cm}^{-2} \mathrm{~s}^{-1}$. This neutron flux value is still lower than the stated acceptance criteria of MTR-type reactors in which the reactor should have a maximum neutron flux in irradiation positions and in the reflector region with high thermal neutron flux of at least in the order of $1.0 \times 10^{15}$ and $0.5 \times 10^{15}$ $\mathrm{n} \mathrm{cm}^{-2} \mathrm{~s}^{-1}$, respectively.

The second conceptual design was proposed by I. Kuntoro, et al., [3] where the grid core is the same but the height of the fuel and power are different. To fulfill that acceptance criterion, the core was designed with the fuel elements of $70 \mathrm{~cm}$ 
height and the power level of $50 \mathrm{MW}$, while the other sizes are the same as the lattices of the previous reactor design. The core configuration is specified by the number and positions of fuel elements and irradiation positions. After finding that the optimum core configuration satisfies the acceptance criterion that the neutron flux in the center of the core is not less than $1.0 \times 10^{15} \mathrm{n} \mathrm{cm}^{-2} \mathrm{~s}$, it is necessary to analyze the dynamics of the core to understand the characteristics of the core from safety standpoint. However, dynamic analysis has not been done for this MTR conceptual core design. For this purpose, the conceptual core design is examined in a transient condition. The calculations performed are concerning rapid transients initiated by positive-reactivity-induced accident during a control rod withdrawal at the power of $1 \mathrm{MW}$. Many researchers have performed neutronic and thermal-hydraulic calculations to understand the safety characteristics of research reactors using PARET, RELAP, COOLOD-N2, and EUREKA codes [4-8]. In this research, the MTR-DYN code is used.

This research is a subsequent evaluation design for conceptual core design of MTR research reactor by focusing on identifying safety limits and margins. Discussed in this research is the dynamic analysis for conceptual core design of an MTR research reactor using MTR-DYN code [9]. Before the analysis is performed, it is started from design calculations and carried out by means of WIMSD-5B [10] for cross-section generation as an input to Batan-3DIFF diffusion code for core calculation [11] to determine the integral and differential control rod worth. The macroscopic cross-section was also needed to calculate the fuel and moderator reactivity coefficient and delayed neutron fraction. To determine the maximum speed of control, a period-reactivity relation was used. The MTR-DYN code was used to determine the thermal-hydraulic parameter to analyze core dynamic as a rapid transient initiated by positive reactivity in the core.

The WIMSD-5B code was used for calculating group constants for different materials in the MTR-type research reactor core. Batan-3DIFF and MTR-DYN codes are used for core calculation. These codes are used for the neutronics and steady state thermal-hydraulic and dynamic parameters which had been verified using RSG GAS core [12].

\section{METHODOLOGY}

The methodology to achieve the research objective can be divided into two types of calculations, namely cell calculation and core calculation. This section elaborates these two calculation types.

\section{Cell calculation}

To solve the neutron kinetics equations, the macroscopic cross-section library for various materials in the core was set up. For this purpose, the WIMSD-5B lattice code was used. In practice, the cells which may correspond to any region of the core (fueled and non-fueled) were identified. When defining the unit cell dimensions, the principle of conservation of volume ratio of the different material in the fuel assembly was considered. The fuel assembly in the core configuration is showed in Fig. 1. The fuel cell dimensions were calculated taking into account the fuel meat conservation criteria. The unit cell for fuel element (FE) is showed in Fig. 2. An extra region is added to keep the remaining water and aluminum in the same proportions as in the physical fuel element. This region includes the aluminum in the plates beyond the width of the meat and the aluminum side plates, the water beyond the width of the meat, and the water channels surrounding the fuel element. In the particular case of control elements, the super-cell option of WIMSD-5B was used. The representative cell was modeled with 15 regions. The control rod and box absorber are showed in Fig. 3 and Fig. 4. The macroscopic crosssection data was generated by WIMSD-5B code as a function of burn-up and fuel and moderator temperatures. Different burnup values, ranging from $0 \%$ to $90 \%$, were considered in order to generate all conditions, beginning of cycle, and end of cycle cores.

Fuel and moderator temperatures were chosen in order to cover a large set of core conditions for normal and transient conditions. The macroscopic cross-section was also performed to determine the average speed of neutrons. The cross-section generation was actually done in four neutron energy groups, but the determination of the average speed of neutrons was carried out in 69 groups of neutron energy. The average speed of neutrons in four groups of power was calculated by weighting the speed of neutrons in the 69 energy groups with a average cell flux. The speed of neutron was used to calculate total delayed neutron fraction.

The steps of cell calculation are as follows [13]:

(i) The macroscopic $\mathrm{x}$-section as a function of burnup was generated under ambient conditions $\left(20^{\circ} \mathrm{C}\right)$, (ii) The macroscopic $\mathrm{x}$-section for fuel element was generated as a function of temperature $\left(50{ }^{\circ} \mathrm{C}, 100\right.$ ${ }^{\circ} \mathrm{C}, 150{ }^{\circ} \mathrm{C}, 200{ }^{\circ} \mathrm{C}$ ), and (iii) The macroscopic $\mathrm{x}$-section for moderator was generated as a function of temperature $\left(35^{\circ} \mathrm{C}, 45^{\circ} \mathrm{C}, 60{ }^{\circ} \mathrm{C}, 100{ }^{\circ} \mathrm{C}\right)$. In this step no moderator density effect was included. 
Table 1. Safety criteria for MTR research reactor using U9Mo-Al fuel

\begin{tabular}{cllc}
\hline No & Parameter & Value & Mark \\
\hline 1 & Reactivity coefficient & - & Negative \\
2 & Max. Power peaking factor & 1.4 & \\
3 & Max. temperature at cladding at & $210{ }^{\circ} \mathrm{C}$ & \\
& full power & & \\
4 & Max. burnup exchanged & $70 \%$ & \\
5 & Analysis to be done for accident & & RIA \\
\hline
\end{tabular}

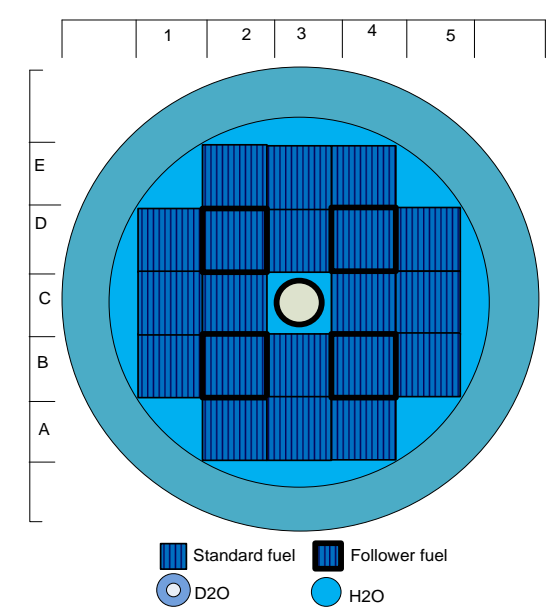

Fig. 1. Core configuration of the MTR-type research reactor [2].

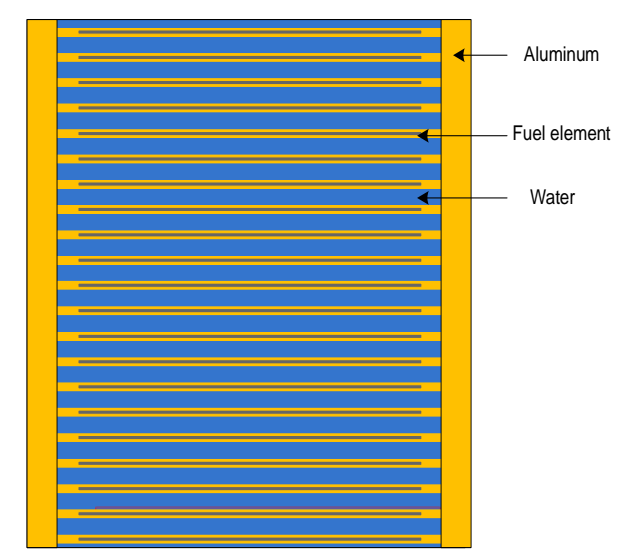

Fig. 2. Standard fuel element [2].

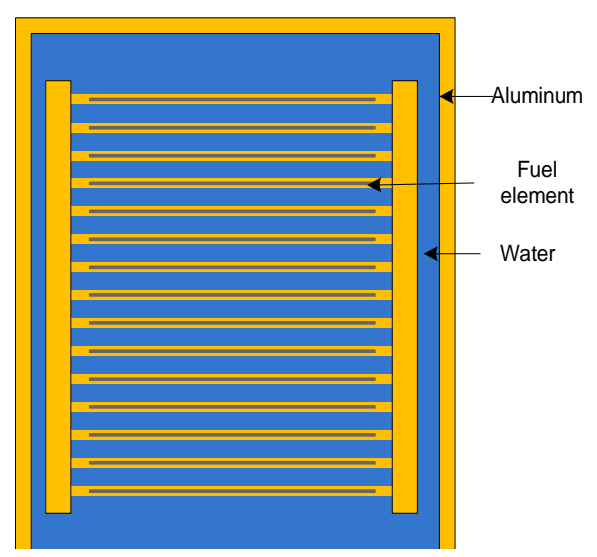

Fig. 3. Fuel follower element [2].

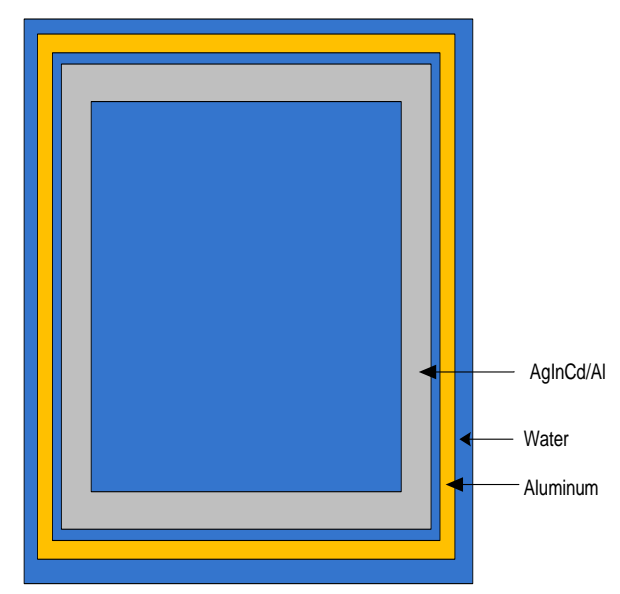

Fig. 4. Control rod element [2].

\section{Core calculation}

Core calculation was done by using Batan2DIFF and Batan-3DIFF codes for reactivity coefficient and for integral and differential control rod worth. Batan-2DIFF was also used to calculate total delayed neutron fraction which is needed as an input for MTR-DYN code for dynamic analysis. The MTR-DYN code is a coupled neutronic $(\mathrm{N})$ and thermal-hydraulic $(\mathrm{T} / \mathrm{H})$ code for the MTR research reactor type. This code was developed using threedimensional multigroup neutron diffusion with finite difference method. The flowchart of $\mathrm{N}$ and steady-state T/H calculations is shown in Fig. 5. All calculations were carried out by the adiabatic method (AM) and Table 1 shows the safety criteria for the analysis [14].

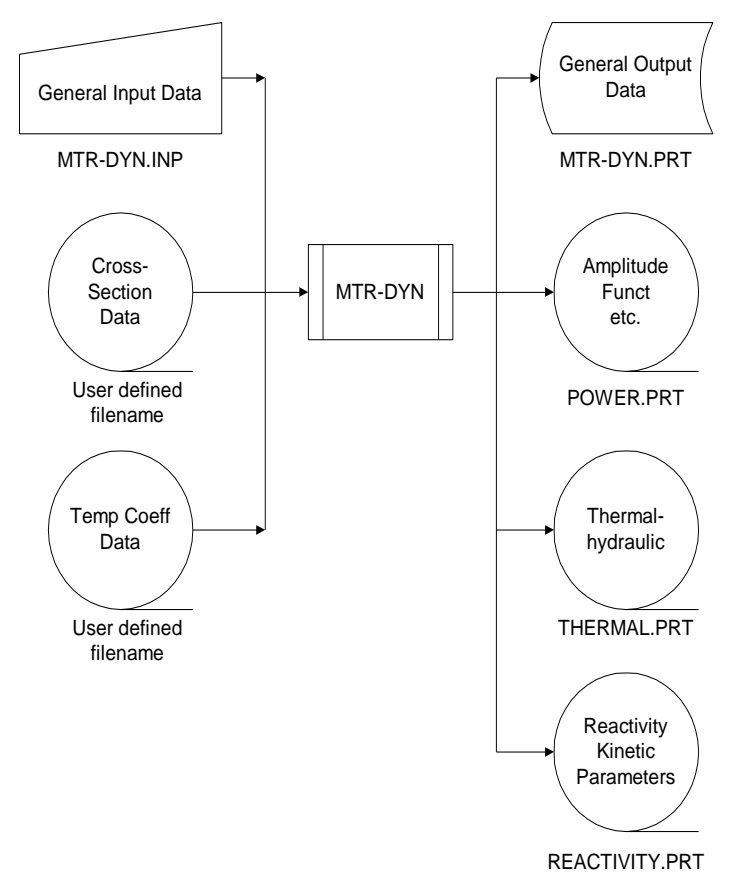

Fig. 5. MTR-DYN code input/output file structure [12]. 


\section{RESULTS AND DISCUSSION}

The neutronic parameters of the MTR-type research reactor are showed in Table 2. The results show that the value of radial power peaking factor $(\mathrm{PPF})$ is $<1.4$, and the maximum neutron flux in the center of the core meets the acceptance criteria $>1.0 \times 10^{15} \mathrm{n} \mathrm{cm}^{-2} \mathrm{~s}$. The value of the PPF on the equilibrium core is far below the safety limit. The PPF value will change due to the pattern and materials exchange in the core. It can be said that the PPF is affected by fuel management. Therefore, the primary factor in determining the maximum value of PPF is the burnup distribution in the fuels and around the control rod positions. The greatest radial PPF value is 1.24 with the largest fraction and was close to the control rod (D-2) position at equilibrium core. The maximum radial PPF value is less than the value of safety limit of 1.4.

Table 2. Neutronic parameters of MTR research reactor

\begin{tabular}{llc}
\hline No. & \multicolumn{1}{c}{ Parameters } & Value \\
\hline 1. & Excess reactivity $[\% \Delta \mathrm{k} / \mathrm{k}]$ & 11.32 \\
2 & Contol rod worth $[\% \Delta \mathrm{k} / \mathrm{k}]$ & -25.60 \\
3. & Maximum radial power peaking factor & 1.23 \\
4. & Cycle length reactor operation (days) & 15 \\
5. & Maximum axial power peaking factor & 2.1 \\
6. & Maximum thermal neutron flux in the & 0.579 \\
& irradiation position $\left(10^{15} \mathrm{n} \mathrm{cm}^{-2} \mathrm{~s}\right)$ \\
7. & $\begin{array}{l}\text { Maximum thermal neutron flux in the center } \\
\text { 8. }\end{array}$ & 1.08 \\
8. & Power density $\left(\mathrm{W} \mathrm{cm}^{-3}\right)$ & 635 \\
\hline
\end{tabular}

Note: Uranium density $=3.96 \mathrm{gU} \mathrm{cm}^{-3}$

\section{Reactor kinetic parameters}

Reactor kinetic parameters such as delayed neutron fraction and prompt neutron lifetime are needed to be determined for dynamic analysis. Table 3 shows that calculation result of delayed neutron fraction and prompt neutron lifetime for research reactor MTR-type using U9Mo-Al fuel with a density of $3.96 \mathrm{~g} \mathrm{~cm}^{-3}$. The bigger the delayed neutron fraction, the easier it is for the core to be controlled when the transient occurs in the reactor. The delayed neutron fraction of the RSG-GAS core was $7.16 \times 10^{-3}$. The reactor kinetic parameters required in this study were the effective delayed neutron fraction $\left(\beta_{\mathrm{k}}\right)$ and the delayed neutron decay constant. Acceptance criteria for a kinetic parameter value such as effective delayed neutron fraction $\left(\beta_{\text {eff }}\right)$ is $\beta_{\text {eff }}=\gamma \beta$, where $\gamma=1.05$ to 1.25 , and $\beta$ is 0.0064 for uranium fuel [15]. The value of the effective delayed neutron fraction total should be in the range of 0.00672 to 0.00840 . Beyond this range, the kinetic parameter $\beta_{\text {eff }}$ will be rejected.
Table 3. delayed neutron fraction for density of $3.96 \mathrm{~g} \mathrm{~cm}^{-3}$

\begin{tabular}{lcc}
\hline Group & $\begin{array}{c}\text { Delayed neutron } \\
\text { fraction }\left(\beta_{\mathrm{k}}\right)\end{array}$ & $\begin{array}{l}\text { Decay constant of } \\
\text { delayed neutron }\left(\lambda_{\mathrm{k}}\right) \mathrm{s}^{-1}\end{array}$ \\
\hline 1 & $2.61123 \times 10^{-4}$ & $1.29065 \times 10^{-2}$ \\
2 & $1.53233 \times 10^{-3}$ & $3.11613 \times 10^{-2}$ \\
3 & $1.69042 \times 10^{-3}$ & $1.34027 \times 10^{-1}$ \\
4 & $2.65407 \times 10^{-3}$ & $3.31390 \times 10^{-1}$ \\
5 & $7.56494 \times 10^{-4}$ & $1.46117 \times 10^{0}$ \\
6 & $2.95836 \times 10^{-4}$ & $3.81104 \times 10^{0}$ \\
Total delayed neutron fraction : $7.19027 \times 10^{-3}$ \\
Average decay constant : $7.84863 \times 10^{-2} \mathrm{~s}^{-1}$ \\
\multicolumn{2}{l}{ Prompt neutron lifetime : $5.549 \times 10^{-5} \mathrm{~s}$} \\
\hline
\end{tabular}

It is important to obtain the sign and magnitude of the various reactivity coefficients because these coefficients suggest the consequences of sudden changes in the operating parameters. A positive value for a reactivity coefficient means that a positive change in that parameter will increase reactivity and tend to increase power. A negative value for a reactivity coefficient means that a positive change in that parameter will decrease reactivity and tend to decrease power. In both cases, a larger absolute value of the reactivity coefficient indicates greater sensitivity to changes in that parameter. The Batan-2DIFF code accurately calculates the fuel and moderator temperature coefficient of reactivity. The calculation results in Table 4 show that the moderator temperature reactivity coefficient is negative. It meets the acceptance criteria when the moderator temperature is changed from $35{ }^{\circ} \mathrm{C}$ to $80{ }^{\circ} \mathrm{C}$. When moderator temperature is changed, the fuel temperature remains constant. Table 5 shows that fuel temperature reactivity coefficient is also negative when the fuel temperature was varied in the $50{ }^{\circ} \mathrm{C}-200{ }^{\circ} \mathrm{C}$ range. Both parameters (moderator and fuel coefficient of reactivity) are significant for feedback reactivity for dynamic analysis. The fuel temperature coefficient is a very prompt effect because fuel temperature changes quickly when power changes. In an accident where the power increases, a negative fuel temperature reactivity coefficient provides a prompt negative feedback that tends to bring power down.

Table 4. Moderator temperature reactivity coefficient

\begin{tabular}{ccccl}
\hline $\begin{array}{c}\text { Moderator } \\
\text { temperature } \\
{\left[{ }^{\circ} \mathrm{C}\right]}\end{array}$ & $\begin{array}{c}\mathrm{k} \text {-eff } \\
{[\% \Delta \mathrm{k} / \mathrm{k}]}\end{array}$ & $\begin{array}{c}\text { Core } \\
\text { reactivit } \\
\mathrm{y}[\rho] \\
{[\% \Delta \mathrm{k} / \mathrm{k}]}\end{array}$ & $\begin{array}{c}\Delta \rho \\
{[\% \Delta \mathrm{k} / \mathrm{k}]}\end{array}$ & $\begin{array}{l}\text { Moderator } \\
\text { reactivity } \\
\text { coefficient } \\
{\left[(\% \Delta \mathrm{k} / \mathrm{k}){ }^{\circ} \mathrm{C}^{-1}\right]}\end{array}$ \\
\hline 35 & 1.03511 & 3.39188 & 0 & - \\
45 & 1.03426 & 3.31313 & -0.07875 & $-7.8760 \times 10^{-3}$ \\
60 & 1.03298 & 3.19296 & -0.12019 & $-8.0130 \times 10^{-3}$ \\
80 & 1.03125 & 3.01865 & -0.17431 & $-8.7510 \times 10^{-3}$ \\
\hline
\end{tabular}


Table 5. Fuel temperature reactivity coefficient

\begin{tabular}{ccccl}
\hline $\begin{array}{c}\text { Fuel } \\
\text { temperat } \\
\text { ure }\left[{ }^{\circ} \mathrm{C}\right]\end{array}$ & $\begin{array}{c}\mathrm{k} \text {-eff } \\
{[\% \Delta \mathrm{k} / \mathrm{k}]}\end{array}$ & $\begin{array}{c}\text { Core } \\
\text { reactivity } \\
{[\rho][\% \Delta \mathrm{k} / \mathrm{k}]}\end{array}$ & $\begin{array}{c}\Delta \rho \\
{[\% \Delta \mathrm{k} / \mathrm{k}]}\end{array}$ & $\begin{array}{l}\text { Fuel reactivity } \\
\text { coefficient } \\
{\left[(\% \Delta \mathrm{k} / \mathrm{k}){ }^{\circ} \mathrm{C}^{-1}\right]}\end{array}$ \\
\hline 50 & 1.04495 & 4.30201 & 0 & - \\
100 & 1.04389 & 4.20448 & -0.09753 & $-1.9506 \times 10^{-3}$ \\
150 & 1.04289 & 4.11343 & -0.09105 & $-1.8210 \times 10^{-3}$ \\
200 & 1.04233 & 4.06118 & -0.05225 & $-1.0450 \times 10^{-3}$ \\
\hline
\end{tabular}

Figure 6 shows the axial power peaking factor for hottest channels resulting from the calculation as the reactor operates at a power of $50 \mathrm{MW}$. The maximum value of axial PPF is 1.9 at the control rod position of $45 \mathrm{~cm}$ of height from the core.

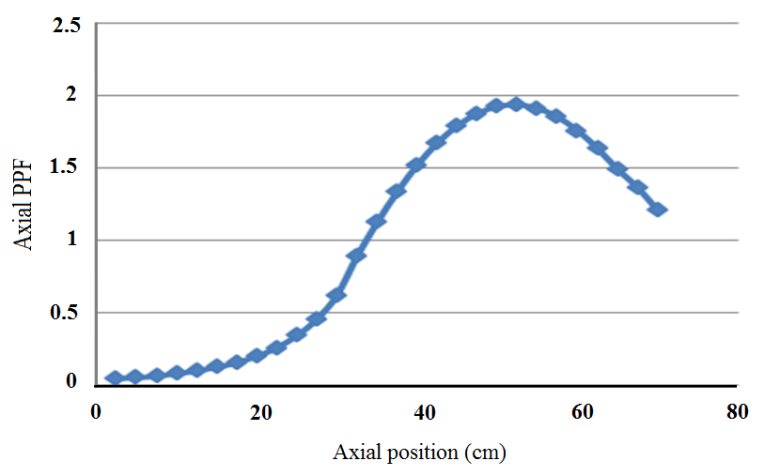

Fig. 6. Maximum axial power density in D-2 core grid position.

\section{Integral and differential control rod worth}

Reduction or increase of thermal utilization factor (f) is an important property of a control rod and depends on $\mathrm{k}_{\mathrm{eff}}$, whether the rod is inserted or withdrawn from the core. The change in $\mathrm{k}_{\text {eff }}$ results in a change in the reactivity of the core. The worth of a control rod directly relates to its effect on reactivity and it has usually the same unit with the reactivity of the core. The effectiveness, or worth, of a control rod, depends on mostly of the value of the neutron flux at the location of the rod. The change in reactivity caused by control rod motion is referred to as control rod worth. For a reactor with a single control rod such as the MTR-type reactor, the control rod's worth has a maximum effect if placed in the center of reactor core having the maximum flux. The difference of the worth of the rod between the inserted and withdrawn positions from the reactor is dependent on the axial flux shape. The flux at the top and bottom of the reactor is typically less than that in the middle. Therefore, the rod worth per unit length of the control rod at the top and bottom of the core is less than that in the middle during insertion or withdrawal. This behavior is typically illustrated in the integral and differential rod worth curves as shown in Fig. 7 and Fig. 8, respectively. Axial power density depends on the volume of the core. In research reactors it is normal that the effective volume of the core is changed because the number of fuel elements in the reactor is not fixed. The control rod worth also depends on the numbers of fuel in the core. The integral control rod worth curve is particularly significant in research reactor operation. For a reactor that has a large amount of excess reactivity, several control rods are required [16]. To gain the full effectiveness of the rods and a relatively even flux distraction, the rods need to be distributed appropriately. The exact worth of each control rod is dependent upon the design of the reactor. The exact effect of control rods on reactivity can usually be estimated. For example, a control rod can be withdrawn in small increments, such as $5 \mathrm{~cm}$, and the change in reactivity can then be determined following each increment of withdrawal. By plotting the resulting reactivity versus the rod position, a graph similar to that in Fig. 7 is obtained. The graph depicts integral control rod worth over the full range of withdrawal. The integral control rod worth is the total reactivity worth at that particular degree of withdrawal and that is mostly defined to be the greatest if the rod is fully withdrawn.

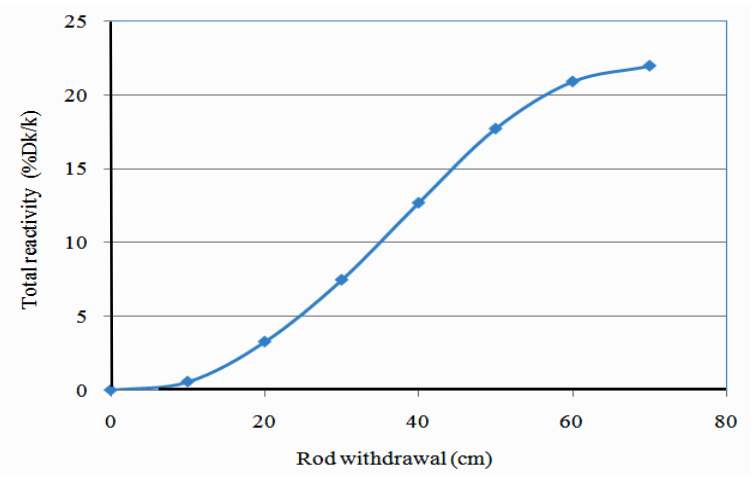

Fig. 7. Integral control rod worth.

Figure 7 shows that the gradient of the curve $(\Delta \rho / \Delta x)$, indicating that the amount of reactivity inserted per unit of withdrawal is the highest when the control rod is halfway out of the core. This occurs due to the area of the highest neutron flux near the center of the core. Therefore, the change of neutron absorption is most effective in this area. If the slope of the curve for integral rod worth in Fig. 7 is taken into account, the rate of change of control rod worth will be a function of control rod position.

A plot of the slope of the integral rod worth curve, or the so-called differential control rod worth, is shown in Fig. 8. It is seen that at the bottom of the core, where there are fewer neutrons, the rod 
movement has little effect due to the little change in reactivity worth per $\mathrm{cm}$. As the rod approaches the center of the core, its effect becomes greater, and hence making the change in reactivity worth per unit length greater. Furthermore, at the center of the core, the differential rod worth is the highest depending on small rod motion. From the center of the core to the top, the rod worth per unit length is basically an inverse of the rod worth per unit length from the center to the bottom.

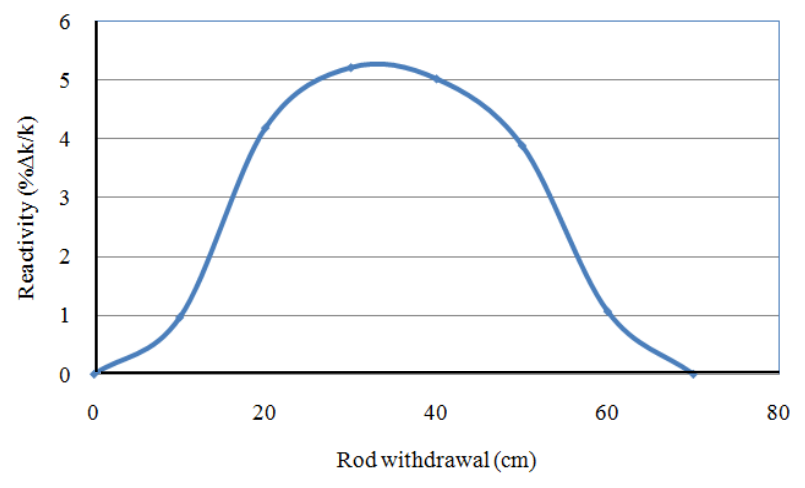

Fig. 8. Differential control rod worth.

The control fuel elements (CFE) are modeled in Batan-3DIFF code, and based on the code's XS requirements, four groups of neutron energy for libraries of XS are provided. This was done by changing the thermal capture cross-section of a region of concern by an amount such that the reactivity of inserted control rod would correspond to the benchmark. The control rod worth is estimated by calculating $k_{\text {eff }}$ with all four absorber boxes inserted in the core. The results are shown in Fig. 7, indicating the axial power shape as a function of the control rod position in the reactor that ranges from fully inserted to fully withdrawn positions. An axial peaking factor of 1.5 is obtained bound by the limit. The effect of the insertion rate on the flux density is illustrated in Fig. 7. In addition, Fig. 8 shows the worth of fully inserted four control fuel elements. The result shows that the gradient is $0.594 \% \Delta \mathrm{k} / \mathrm{k} \mathrm{cm}^{-1}$. By adding a safety factor of $15 \%$, a value of $0.68 \% \Delta \mathrm{k} / \mathrm{k} \mathrm{cm}^{-1}$ is obtained. From Fig. 8, which shows the differential worth of control fuel elements, it can be said that the control rod is most effective at the position of $25-40 \mathrm{~cm}$. In addition, the control rod worth is surely affected by such factors as burnup of neutron absorbers, follower fuel, and distribution of fuels in the reactor core.

\section{Period-reactivity relation}

To calculate the control rod velocity, the POKDYN program is used. The program, written in
Fortran, consists of main program, POKS subroutine, POKIN subroutines, and REACH function that uses point kinetic equations to complete the calculation in terms of neutronic transient conditions and accidents due to reactivity insertion. The calculations of period-reactivity relationship were performed using the data given in Table 2, Table 3, and Table 4.

Reactivity cannot be directly measured and in most research reactors, procedures do not refer to it and most technical specifications do not limit it. Instead, they specify a limiting rate of power rise (measured by detectors), commonly called the reactor period (especially in the case of MTR-type reactor). The smaller the value of $\tau_{\mathrm{e}}$, the more rapid the change in reactor power. The reactor period may be positive or negative. As the reactor period is positive, reactor power increases or vice versa. If the reactor period is constant with time, as associated with exponential power change, the rate is referred to as a stable reactor period. However, if the reactor period is not constant but is changing with time, as for non-exponential power change, the period is referred to as a transient reactor period. According to German system (SUS), once the reactor period (reactor doubling time) falls under $10 \mathrm{~s}$, power increases fast and a power scram is set [16].

A much more exact reactor period formula is based on solutions of six-group point kinetics equations. From these equations, an equation, called the in-hour equation (which comes from the inverse hour, when it was used as a unit of reactivity that corresponded to e-fold neutron density change during one hour), may be derived. The reactor period, $\tau_{\mathrm{e}}$, or e-folding time, is defined as the time required for the neutron density to change by a factor $\mathrm{e}=2.718$. The reactor period is usually expressed in the unit of seconds or minutes. For the MTR-type research reactor, an acceptance criterion is a period of $>10 \mathrm{~s}$. Figure 9 shows the relation of period and reactivity for an MTR-type research reactor. The result showed that for control rod speed of $0.0564 \mathrm{~cm} \mathrm{~s}^{-1}$, the period is more than $10 \mathrm{~s}$. If the speed of the control rod changes to $0.075 \mathrm{~cm} \mathrm{~s}^{-1}$, the period of the core is still more than $10 \mathrm{~s}$. This is also the case as the speed changes to $0.0846 \mathrm{~cm} \mathrm{~s}^{-1}$. However, when the speed of the control rod increases to $0.12 \mathrm{~cm} \mathrm{~s}^{-1}$, the period becomes less than $10 \mathrm{~s}$. This means that the maximum control rod for the MTR-type research reactor is $0.0846 \mathrm{~cm} \mathrm{~s}^{-1}$.

\section{Thermal-hydraulics and dynamics analysis}

The coolant mass flow rate in the MTR-type research reactor is limited by the flow instability phenomenon. A reactor with a high thermal power can incur flow instability characterized by a flow excursion. Basically, flow rates that are too low will 
not remove the heat efficiently from the cladding, and the efficiency of the system will be low. However, flow rates that are too high will require larger pumps and plumbing that increase both initial and operating costs. For higher uranium densities, the thickness of the plate or the channel width is increased so that the reactor is stable at a high flow rates. In addition to reducing the heat flux in the fuel, it can be done by increasing the fuel height so the maximum temperature of fuel and cladding will be reduced. From calculations, the maximum coolant flow rate was obtained as $900 \mathrm{~kg} \mathrm{~m}^{-2} \mathrm{~s}^{-1}$. By using the mass flow in the core of $900 \mathrm{~kg} \mathrm{~s}^{-1}$, the maximum coolant velocity at fuel channel is found to be $12.29 \mathrm{~m} \mathrm{~s}^{-1}$.

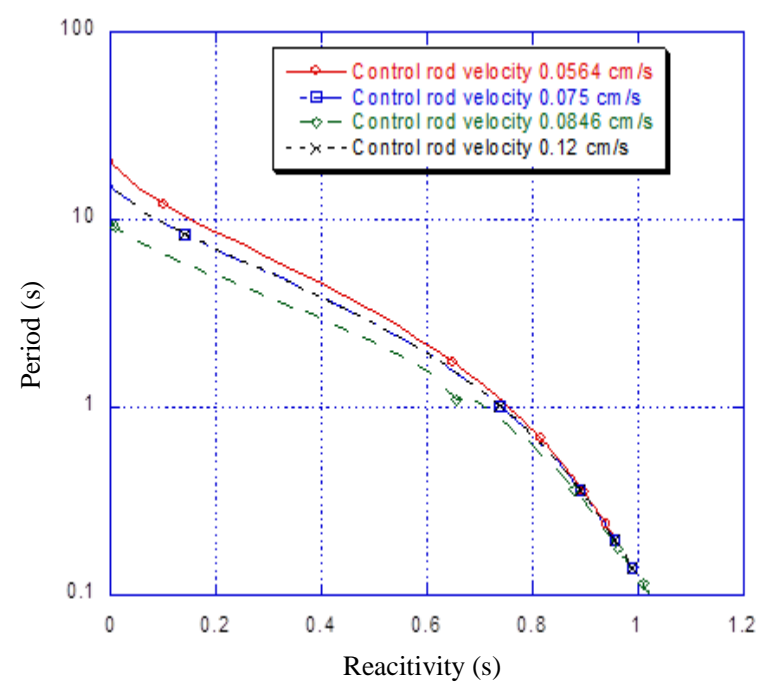

Fig. 9. Maximum control rod speed.

Starting from the initial conditions of core temperature of $45^{\circ} \mathrm{C}$ and $2 \%$ nominal for the power (1 MW), a ramp reactivity of $51 \mathrm{pcm} \mathrm{s}^{-1}$ was inserted for $16 \mathrm{~s}$. The fuel and moderator temperature feedback coefficient of reactivity are noted in Table 3 and Table 4. Figures 10 and 11 show the development of calculated relative reactor power and average core temperature. The comparison to the safety limit $210{ }^{\circ} \mathrm{C}$ of maximum fuel temperature depicts good calculation result compared with safety limit. Starting from the initial value the power increases to about $66 \mathrm{MW}$ of power, the average core temperature escalates to about $76{ }^{\circ} \mathrm{C}$. This behaviour stimulates the negative reactivity feedback effect that is able to consume the entire available excess reactivity at this point, forcing the power to decrease and demonstrating the inherently safety features of conceptual reactor core. Sometimes, it is difficult to measure the cladding or fuel temperature in a research reactor. Thus, the calculated temperatures are used to evaluate the consequences of an accident. During the accident, the calculated maximum fuel and cladding temperatures of the central channel amount to
$196{ }^{\circ} \mathrm{C}$ and $192{ }^{\circ} \mathrm{C}$, respectively. Thus, the maximum cladding temperature is far from the fuel temperature safety limit of $210{ }^{\circ} \mathrm{C}$, ensuring that no sub-cooled boiling occurs. Hence, the transient indicates that the attained power peak of about $66 \mathrm{MW}$ does not affect the fuel elements, since no DNB is to be expected under these conditions.

During RIA events, the core becomes supercritical and generally core power rises to level beyond the heat removal system capability. For this reason, such events are considered one of the most severe transients that could lead to core damage. To understand the dynamics of such phenomena, it is necessary to identify the various key parameters that govern the power excursion shape, the inherent self-limiting behavior, the power, and the released energy. These later are mainly governed by the prompt neutron lifetime that are used in the core. There are also the delayed neutron fraction, reactivity coefficient related to complex interactions of the physical process between kinetics and thermal-hydraulics phenomena, and the response of the reactor control system. The MTR-type research reactor core with 390 grams of fuel loading corresponds to ramp reactivity of $51 \mathrm{pcm} \mathrm{s}^{-1}$. In this case, the role of prompt (Doppler reactivity) and delayed coolant temperature rise feedback effects and they are emphasized in all the consideration transients. The scram system is activated when the reactor power reaches $59 \mathrm{MW}$. Since there is a 0.5 -second delay to actuation of the control rod scram system, the power increases to $66 \mathrm{MW}$. When the reactor power increases to $66 \mathrm{MW}$, the fuel, cladding, and coolant temperatures reach $196{ }^{\circ} \mathrm{C}, 192{ }^{\circ} \mathrm{C}$, and $76{ }^{\circ} \mathrm{C}$, respectively, but they are still below the safety limit of $210{ }^{\circ} \mathrm{C}$. The temperatures of the fuel, coolant, and cladding should be limited to maintain the integrity of the fuel. Table 6 shows the maximum temperature in the fuel, cladding, and moderator. It was stated that reactions of $\gamma \mathrm{UMo}$ alloys with aluminum started typically at the temperature of $645{ }^{\circ} \mathrm{C}$ [17]. A temperature of $641{ }^{\circ} \mathrm{C}$ for the melting point of the aluminum was also indicated, and it is suggested that chemical reaction started soon after the melting phenomena. Thus, the validity of the fundamental assumptions of their approach to the detection of possible reactions in the U-Mo-Al system is confirmed. The formation of a layer of liquid aluminum in contact with the $\gamma \mathrm{UMo}$ particles promotes an effective contact between both surfaces, enhancing the probability of reaction. Therefore, the fuel and cladding temperatures are still far below the melting point of the aluminum cladding.

Figure 10 shows the power and reactivity profile after insertion of $51 \mathrm{pcm} \mathrm{s}^{-1}$ of reactivity. After 16 seconds, the maximum power reaches 
$66 \mathrm{MW}$, and then the reactor scrams by setting point at $118 \%$ of maximum power. Figure 11 shows the temperature profile of fuel, cladding, and moderator. The maximum temperature is still below the safety limit for the U9Mo-Al fuel.

Table 6. Maximum temperature with various uranium density at fuel elements

\begin{tabular}{ll}
\hline Parameters & Value \\
\hline Coolant temperature at core inlet $\left[{ }^{\circ} \mathrm{C}\right]$ & 44.5 \\
Coolant temperature at core outlet $\left[{ }^{\circ} \mathrm{C}\right]$ & 60.50 \\
Maximum temperature at coolant $\left[{ }^{\circ} \mathrm{C}\right]$ & 76.0 \\
Maximum temperature at cladding $\left[{ }^{\circ} \mathrm{C}\right]$ & 192.0 \\
Maximum temperature at fuel meat $\left[{ }^{\circ} \mathrm{C}\right]$ & 196.0 \\
\hline Note: Uranium density $=3.96 \mathrm{~g} \mathrm{~cm}^{-3}$ &
\end{tabular}

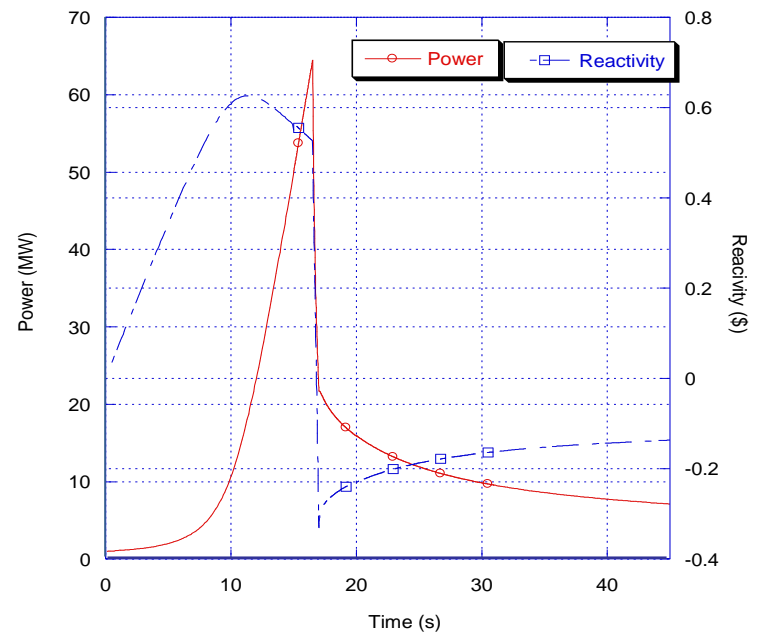

Fig. 10. Power and reactivity of the core as transient.

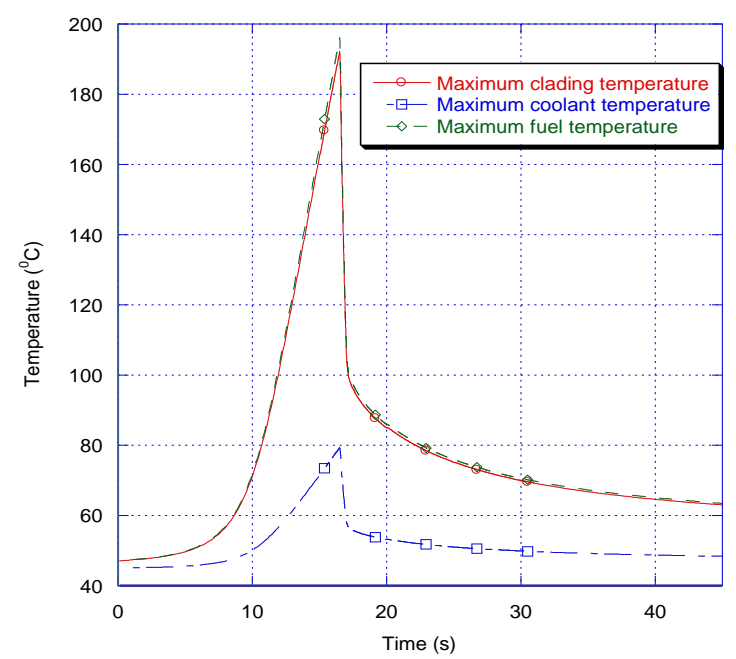

Fig. 11. Maximum fuel, cladding and moderator temperatures.

\section{CONCLUSION}

Core configuration, including a number of in-core irradiation positions, has a strong influence on the value and distribution of neutron fluxes either in-core or in the reflector region. The neutron flux in the core region can be increased by adding an in-core irradiation position. The outer irradiation positions have the biggest influence on increasing the neutron flux in the reflector region. For the MTR-type research reactor, based on the equilibrium core, the best core is attained using a fuel density of $3.96 \mathrm{~g} \mathrm{~cm}^{-3}$ that provides many irradiation positions with highest neutron fluxes. Based on the calculation with the MTR-DYN code, it is clear that the uranium density of $3.96 \mathrm{~g} \mathrm{~cm}^{-3}$ for U9Mo-Al fuel that is proposed in this research work can be utilized as a candidate fuel for the RRI reactor core. The neutronics and thermal-hydraulics criteria are fulfilled with no safety limits exceeded. Fuel cladding strain limit is not exceeded during the anticipated transient with a thermal power of $50 \mathrm{MW}$. The dynamic characteristics of the core have to be carry out with a core configuration of $3.96 \mathrm{~g} \mathrm{~cm}^{-3}$ at the optimum uranium density of U9Mo-Al fuel for MTR research reactor without safety rod which proposed in this research can be applied with good safety features.

\section{ACKNOWLEDGMENT}

The authors wish to express special thanks to Dr. Jupiter S. Pane MSc. and Ir. Tagor Malem Sembiring for his fruitful discussions and to Dr. Geni Rina Sunaryo, head of PTKRN, for her support, and also thank the Management of PTKRN. This research was funded from the DIPA of PTKRN Year 2010-2014.

\section{REFERENCES}

1. F. Muhammad and A. Majid, Prog. Nucl. Energy 51 (2009) 339.

http://dx.doi:10.1016/j.pnucene.2008.06.003

2. T. Surbakti, S. Pinem, T.M. Sembiring et al., Tri Dasa Mega 14 (2012) 179. (in Indonesian)

3. I. Kuntoro and T. M. Sembiring, Tri Dasa Mega 16 (2014) 1. (in Indonesian)

4. H. Kazeminejad, Ann. Nucl. Energy 45 (2012) 59. http://dx.doi:10.1016/j.anucene.2012.02.017

5. I.D. Abdelrazek, M. Naguib Aly, A.A. Badawi et al., Ann. Nucl. Energy 70 (2014) 36. http://dx.doi.org/10.1016/j.anucene.2014.02. 023

6. X. Shen, K. Nakajima and H. Unesaki et al., Ann. Nucl. Energy 62 (2013) 195. http://dx.doi.org/10.1016/j.anucene.2013.06.014

7. M.A. Albatia and S.O. AL-Yahiaa, J. Park et al., Prog. Nucl. Energy 71 (2014) 1 http://dx.doi.org/10.1016/j.pnucene.2013.10.015 
8. D. Jo, J. Park and H. Chae, Prog. Nucl. Energy 71 (2014) 39.

http://dx.doi.org/10.1016/j.pnucene.2013.11.006

9. S. Pinem, T.M. Sembiring and Setiyanto, Tri Dasa Mega 11 (2009) 153. (in Indonesian)

10. T. Surbakti and T.M. Sembiring, Tri Dasa Mega 18 (2016) 29. (in Indonesian)

11. L. Suparlina and T. Surbakti, Tri Dasa Mega $\mathbf{1 6}$ (2014) 89. (in Indonesian)

12. S. Pinem, T.M. Sembiring and P.H. Liem, Atom Indonesia 42 (2016) 123. http://dx.doi.org/10.17146/aij.2016.532.
13. Rokhmadi and T. Surbakti, Tri Dasa Mega $\mathbf{1 5}$ (2013) 77. (in Indonesian)

14. A. Hedayat, Prog. Nucl. Energy 71 (2014) 61. http://dx.doi.org/10.1016/S0149-1970 (14) 00018-3

15. S. Pinem and I. Kuntoro, Teknologi Bahan Nuklir 10 (2014) 1. (in Indonesian)

16. R. Nasira, M.K. Buttb, S.M. Mirzac et al., Ann. Nucl. Energy 85 (2015) 869. http://dx.doi.org/10.1016/j.anucene.2015.07.003

17. H.J. Ryu and Y.S. Kim. Nucl. Eng. Technology 46 (2014) 159.

http://dx.doi.org/10.5516/NET.07.2014.705 